DOI https://doi.org/10.18551/rjoas.2018-09.28

\title{
REVITALIZATION AND RITUAL IN CIHIDEUNG (DISTRICT OF WEST BANDUNG, WEST JAVA, INDONESIA)
}

\author{
Setyobudi Imam \\ Postgraduate Program, FISIP University of Padjadjaran, Indonesia \\ Gunawan Budhi, Rajab Budi, Suwartapradja Opan S. \\ FISIP University of Padjadjaran, Indonesia \\ *E-mail: setyobudiimam@gmail.com
}

\begin{abstract}
Currently, there is a rise of collective action revitalizing long-extinct ritual rites. The activity involved various actors from various professions (choreographers, dancers, state civil apparatus, agribusiness farmers, village officials). The question arises whether the results of the revitalization using the art of incident approach can be classified as ritual rites? Researchers used qualitative research methods with primary and secondary data types to answer the research question. The hypothesis stated that ritual resulting from revitalization using incident art approach is not a ritual rite. The research result indicated that ritual rites resulting from revitalization are spectacle attractions for the benefit of tourism and the development of contemporary art.
\end{abstract}

\section{KEY WORDS}

Ritual revitalization, happening art approach, rite, tourism.

This research concerns the revitalization of conservation of the springs ritual (ngalokat jeung ngaruat sirah cai or numbal sirah cai) utilizing happening art as an effort to revive local wisdom that has long been neglected while at the same time promoting Cihideung agrotourism (Parongpong, West Bandung, West Java, Indonesia). Collective action emerged at the initiative of choreographers, leaders of Padepokan Kalang Kemuning, Head of Culture Development Section of West Bandung Regency Culture and Tourism Office, Head of Culture Section of West Java Province Tourism and Culture Office, Pikiran Rakyat newspaper reporter in West Java, the Giri Mekar Farmer Group, and the village apparatus.

Researchers refer to previous revitalization studies that differ from the locus of this research, such as Reza 2009, Hudayana et. al. 2012, Indiyanto et. al. 2012, Sutiyono and Seriati 2013, and Rinaldi 2014. Similarly, other studies with a locus (Cihideung) similar to this research, such as Rusnanto 2010, Insantika 2011, and Herlinawati 2011. The previous studies were merely descriptions of ritual aspects, ritual symbol meanings, and traditions.

Researchers reviewed previous studies without critical review of the phenomenon and have not traced what approach was taken to revitalize it. They ignored the critical question of the revitalization phenomenon being studied as a ritual or not. The researchers used one assumption without questioning whether the critical assumptions were correct or false. They assume the phenomenon that is examined is rituals of traditional society. In fact, the variety of activities to revitalize ritual traditions was not necessarily rituals.

Research question concerns whether Upacara Irung-irung (Irung-Irung Ritual) which revitalizes ngalokat jeung ngaruat sirah cai ritual (spring) through happening art approach is truly a traditional ritual? Such research questions have never been the subject of prior research.

\section{LITERATURE REVIEW}

Tradition is a special social inheritance that prevails with its strong ties to present life. The parameter is the closeness between the past and present, that the continuity of the past 
in the present is not just a present fact originating from the past (Sztompka 2010: 70). A tradition exists because humans need to be able to survive (Shils 1981: 322 ) and are closely related to its function (Sztompka 2010: 74-77).

Revitalization is a collective action that seeks to revive and revitalize traditions existed in the past by exploring and developing tradition, economy, social life, culture, and the natural environment potential. Revitalization aims to improve village or city environment quality in an endeavor to increase the quality of life of its inhabitants (Sutiyono and Seriati 2013). Giddens (2001: 37) states that the tradition was initially intentionally created which at times can be repeated later. Collective actions to revitalize arise from conditions that are considered a threat to the existence of a society (Hobsbawn and Ranger 1983). The goal, a set of practices that are arranged by a set of open or hidden rules, both in the form of ritual and symbolic, an upgrade of values and norms (Hobsbawm and Ranger 1983: 1). Sztompka elaborated further, that it was done as a basis for the legitimacy of actual political actions, efforts to mobilize support (participation) of the ongoing program, enhance the image of leaders, or strengthen the spirit of nationalism (2010: 68). Ancient materials were used for modern purposes (Giddens 2003: 70).

Revitalization requires a certain approach. In this case, the approach uses the happening art. The essence of the happening theory according to Hansen (1965: 85) is the idea that there is a fusion of art and life. Akin to life, happening art is an art form of probability and opportunity. It is an art form that is made from all actions, products, materials, objects, sounds, sounds. Its form is integrated through the events that are the result of life as everyone should take and practice every day. Hansen calls it a collage. Artists feel challenged by the need for the demands of their work, therefore, they become more involved with the environment. It involved where they are located, housing, city, village environment, etc. Sugiharto (2013: 20) stated that 'in a work of art, the most important thing is not what it means, but what it does': what art did to its beholder, what beholder felt from the art, then the beholder find its meaning. This meaning is relative because it is very subjective (2013: 29). Thus, the happening art is similar to framing public and everyday space with art (Haedicke 2013: 1).

According to Turner (1974: 6), ritual ceremonies are forms of rite acting as an entrance to understanding the main essence of the formation of a society. There are four roles of rites in society: conflicts deterrence, elimination of divisions and fostering a bond of solidarity, uniting contradictions and differences, and generating new strengths and motivations to ensure the community survival as well as strengthen its ties. However, the rites in the community differ in categories depending on the level and type of society.

In pre-industrial tribal communities which did not recognize the strict separation between work and game space, or not separated between work and leisure time, it is related to liminality. In industrial postal communities which had recognized the separation between work and leisure time and the distinction between when to work and when to play, it is connected with a liminoid (Turner 1974: 131-132; 1982: 55-60).

Free time or leisure reflects radical freedom. According to Turner (1982: 36-37), free time is connected with two kinds of freedom, namely freedom from and freedom for. Free time represents freedom from work routine obligations. Thus, there is freedom to use the symbolic world such as sports, lifestyle, games, watching spectacles (drama, dance, literature), watching movies, reading novels, and so on. On the contrary, there is intentional liminality to clarify and reinforce the limitations and rules.

Researchers put forward a hypothesis stating that Upacara Irung-irung offers invented tradition attraction based on rite revitalization of buhun (ancient) numbal sirah cai through happening art approach.

\section{METHODS OF RESEARCH}

Researchers conducted a study in Cihideung Village (Parongpong Subdistrict, West Bandung Regency) which is located north of Bandung City which is about 16 kilometers long and travels overland in normal conditions about 53 minutes. In 2016, the population reached 
16,820 people. This area no longer possesses irrigated wet paddy and dry paddy fields. The characteristics of the community based on livelihoods are as follows: the agricultural sector is 1,061 people and outside the agricultural sector is 1,833 people $(63 \%)$. The developing agricultural sector is floriculture agribusiness (Ayesha 2016: 135).

Upacara Irung-irung activity located in a spring found in a former tea plantation owned by PTPN VIII. Irung-irung springs are located within Kampung Kancah area, RW (Community Association) 14. Activities took place in several stages. The first phase was conducted on Wednesday, September 20, 2017. It was conducted in the form of bebersih solokan (trench cleaning) involving a number of heads of RW 11, 12 and 13 with a total population of around 30 people. The second stage was conducted on Saturday, September 23, 2017, in the form of Upacara Irung-irung. The third stage is on Sunday, September 24, 2017, in the form of Cihideung Festival (Cifes) which presented flower carnival by dancers under Padepokan Kalang Kemuning.

Researchers used qualitative research methods to obtain two types of data, namely primary and secondary data. The researcher obtained primary data through interviews and direct observation. Researchers obtained secondary data sourced from the Central Statistics Agency, scientific journals, printed material, and online newspapers and magazines, and other social media (blogs, websites, youtube) that met the need to answer their research questions.

The actors as the core team (main) consist of several people as presented in Table 1.

Table 1 - Actors of Upacara Irung-irung

\begin{tabular}{|c|c|c|}
\hline No. & Actors & Agency \\
\hline 1 & $\begin{array}{l}\text { Yanto } \\
\text { Susanto } \\
\text { (Abah Yanto) }\end{array}$ & $\begin{array}{l}\text { dancer and trainer of Jaipongan and Sunda Dance, founder and manager of Padepokan } \\
\text { Kalang Kemuning in Cihideung, rental of Sundanese traditional wedding clothes, wedding } \\
\text { decorations, a farmer in possession of the land, traders of ornamental and fruit crops, } \\
\text { shop owners of agricultural products, members of KTGM, migrants who became residents } \\
\text { of Cihideung }\end{array}$ \\
\hline 2 & $\begin{array}{l}\text { Mas Nanu } \\
\text { Munajat } \\
\text { (Abah Nanu) }\end{array}$ & $\begin{array}{l}\text { Civil servant dance lecturer, dance stylist (choreographer), founder of Padepokan Kalang } \\
\text { Kemuning, conceptor and designer of Ceremonies at the Cihideung Parongpong and } \\
\text { Ngaruat Bumi Districts (Hajat Buruan and Rempug Tarung) in Cikareumbi Village Cikidang } \\
\text { Village Lembang District, not Cihideung residents }\end{array}$ \\
\hline 3 & $\begin{array}{l}\text { Yudi Setiadi } \\
\text { (Yudi Arab) }\end{array}$ & $\begin{array}{l}\text { freelance composer, pengrawit (gamelan performer), Padepokan Kalang Kemuning, not a } \\
\text { Cihideung resident }\end{array}$ \\
\hline 4 & $\begin{array}{l}\text { Retno } \\
\text { Heriyanto } \\
\text { (Kang Adi) }\end{array}$ & $\begin{array}{l}\text { Journalist of the Pikiran Rakyat Daily News Art and Culture Rubric, not a Cihideung } \\
\text { resident }\end{array}$ \\
\hline 5 & $\begin{array}{l}\text { Drs. Hernandi } \\
\text { Tismara }\end{array}$ & Head of Section (Kasi) Bina Budaya Disbudpar BB Regency, not a Cihideung resident \\
\hline 6 & $\begin{array}{l}\text { Drs. Wahyu } \\
\text { Iskandar, } \\
\text { M.MPd. }\end{array}$ & Head of Disparbud Culture Division of West Java Province, not a Cihideung resident \\
\hline 7 & Adil Hendra & $\begin{array}{l}\text { Management of the Giri Mekar Farmers Group (KTGM) which is a farmer and trader } \\
\text { organization of ornamental and cut flowers, a member of the Cihideung BPD, farmer, } \\
\text { trader of ornamental plants and fruit, cut flowers, a Cihideung resident }\end{array}$ \\
\hline 8 & Ayi Kosasih & $\begin{array}{l}\text { Cihideung Village Chief and landowner cultivating ornamental plants and cut flowers, the } \\
\text { person in charge of activities, Cihideung residents }\end{array}$ \\
\hline 9 & $\begin{array}{l}\text { Dede } \\
\text { Koswara }\end{array}$ & $\begin{array}{l}\text { Chairman of RW (Community Association) } 14 \text { Kampung Kancah, Chairman of the } \\
\text { Cihideung Festival Committee and Ceremony of Irung-irung, owners of cultivated } \\
\text { landscapes and cut flowers, residents of Cihideung }\end{array}$ \\
\hline 10 & Aep Saefudin & $\begin{array}{l}\text { Chairman of RW } 13 \text { Kampung Panyairan, farmers cultivating ornamental and fruit plants } \\
\text { as well as traders, residents of Cihideung }\end{array}$ \\
\hline 11 & Asep Adang & $\begin{array}{l}\text { Chairman of RW } 12 \text { Kampung Panyairan, farmers cultivating ornamental plants and cut } \\
\text { flowers as well as traders, residents of Cihideung }\end{array}$ \\
\hline 12 & Isur & $\begin{array}{l}\text { Chairman of RW 11, Panyairan Village, farmers of ornamental plants and traders, } \\
\text { residents of Cihideung }\end{array}$ \\
\hline 13 & Totok & $\begin{array}{l}\text { Chairman of RW } 10 \text { Panyairan Village, farmers cultivating ornamental plants as well as } \\
\text { traders, residents of Cihideung }\end{array}$ \\
\hline 14 & $\begin{array}{l}\text { Haji Alex } \\
\text { Sutisna (Abah } \\
\text { Encu) }\end{array}$ & $\begin{array}{l}\text { a former security guard at a hotel in Cihideung, a farmer who rents the cultivation land of } \\
\text { ornamental plants, a key interpreter for Irung-irung spring, from Purwakarta (a migrant) } \\
\text { who became Cihideung resident }\end{array}$ \\
\hline
\end{tabular}




\section{DISCUSSION OF RESULTS}

The Regional Government of West Java Province and West Bandung Regency has established Cihideung Village as an agrotourism destination. One of the eleven directions of development policy and the economy of West Java is the development of ecotourism, agrotourism, cultural tourism, and pilgrimage. The Cihideung agrotourism area is included in 60 tourist attraction of West Java Province document, and one of three main tourist attraction of West Bandung Regency.

Since 2002, newly established Culture and Tourism Office (Disbudpar) ${ }^{1}$ West Java Province pursues the direction of tourism development policy which refers to the West Java Province Regional Spatial Plan (RTRW) 2002. Tourism activities must not disturb and interfere with cultural sustainability, natural beauty, and the environment (West Java Regional Development Planning Agency 2016: 5).

Table 2 - Comparison of Procession Sequence

\begin{tabular}{|c|c|c|c|}
\hline No & Stage & Numbal Sirah Cai & Upacara Irung-irung \\
\hline \multirow[t]{3}{*}{1.} & \multirow{3}{*}{$\begin{array}{l}\text { Pre- } \\
\text { Ceremony }\end{array}$} & \multirow{3}{*}{$\begin{array}{l}\text { Ngamunikeun lembur included } \\
\text { bebersih sirah cai and solokan } \\
\text { (cleaning the waterways) }\end{array}$} & Bebersih sirah cai dan solokan \\
\hline & & & $\begin{array}{l}\text { Prepare offerings and cone. } \\
\text { A keymaster (custodian of the graveyard) and a } \\
\text { number of shamans fasted the day before. }\end{array}$ \\
\hline & & & Gather in Padepokan Kalang Kemuning \\
\hline \multirow[t]{12}{*}{2.} & \multirow[t]{12}{*}{ Ceremony } & \multirow{3}{*}{$\begin{array}{l}\text { Burn incense, ignite cigars and } \\
\text { cigarettes, and while reading spells }\end{array}$} & The procession goes to the spring \\
\hline & & & Burn incense and read spells \\
\hline & & & ljab Kabul \\
\hline & & \multirow[t]{2}{*}{ ljab kabul directed to karuhun } & Prayer \\
\hline & & & $\begin{array}{l}\text { Message from the Disparbud Culture Office of } \\
\text { West Java Province and the handover of sacrificial } \\
\text { sheep }\end{array}$ \\
\hline & & \multirow{4}{*}{$\begin{array}{l}\text { Slaughtering a goat which is then } \\
\text { buried near the spring }\end{array}$} & The official cut the tumpeng rice \\
\hline & & & Garut sheep slaughter \\
\hline & & & Cakrub Cai \\
\hline & & & Sasapian \\
\hline & & \multirow{3}{*}{$\begin{array}{l}\text { Skin the goat, then cook the goat into } \\
\text { the curry and satay (skewer) }\end{array}$} & Skin the sheep and skewer it \\
\hline & & & Sheep skewers feast \\
\hline & & & $\begin{array}{l}\text { Ketuk Tilu by the Taman Sari Zoo Farmers group } \\
\text { Bandung }\end{array}$ \\
\hline \multirow[t]{2}{*}{3.} & \multirow[t]{2}{*}{$\begin{array}{l}\text { Post } \\
\text { Ceremony }\end{array}$} & $\begin{array}{l}\text { Nasi tumpeng feast and congcot in one } \\
\text { of elders house featuring goat curry } \\
\text { and skewers } \\
\text { - }\end{array}$ & $\begin{array}{l}\text { Cihideung Festival in the form of miniature garden } \\
\text { decoration competition and flower carnival }\end{array}$ \\
\hline & & $\begin{array}{l}\text { Residents of all villages perform social } \\
\text { dances Ketuk Tilu buhun }\end{array}$ & $\begin{array}{l}\text { Residents of RW } 10,11,12,13 \text { still keep throwing } \\
\text { non-organic garbage into the ditch where the } \\
\text { spring water Irung-irung flows }\end{array}$ \\
\hline
\end{tabular}

Disbudpar West Bandung Regency develops tourism by referring to the foundation of the RTRW in West Java Province 2002, the Provincial Regulation of West Java Number 1 of 2008 concerning the control of spatial use in the North Bandung Region, one of which targets conservation areas around springs in Cihideung Village (Parongpong), and West Bandung Regency Regulation Number 2 of 2012 concerning the West Bandung Regency Spatial Plan for 2009-2029 which regulates the spatial planning of the regency aiming to realize the district as an Agroindustry and Eco-Friendly Tourism Regency. The focus of tourism leads to rural and cultural tourism. Thus, Disbudpar of West Bandung Regency identifies tourism potential for development and management of tourism villages using community

\footnotetext{
${ }^{1}$ The establishment of the Department of Culture and Tourism (Disbudpar) of West Java Province based on the West Java Governor's Regulation Number 15 of 2000 refers to Government Regulation (PP) Number 25 of 2000. West Java Disbudpar is a merger of four institutions, namely the West Java Provincial Tourism Office, West Java Provincial Education Office Culture, Regional Office of the Department of Tourism, Post and Telecommunications of West Java Province, and Regional Office of the Ministry of Education in the Field of Culture. The replacement of the name of the Department of Culture and Tourism of West Java Province became the West Java Province Disparbud based on PP No. 38/2007 concerning the distribution of governmental affairs between the provincial and district governments.
} 
empowerment programs. The tourist village emphasizes the appeal of beautiful, natural, and authentic rural atmosphere such as social life, economy, local customs, building architecture, and unique village spaces.

The development refers to sustainable tourism. The development result is a form of tourism products in the village that can be developed as a variety of tour packages and village tourist attractions. The aim is to increase the number of tourist visits, length of stay, shopping for local products, and investment growth in tourism and culture.

The occurring issue is how to revitalize local wisdom that has been a vacuum for a long time and can be seen as an appearance capable to attract the audience due to existing elements containing attractions and aesthetics. Cihideung village as an agrotourism area possesses a number of plants and ornamental flowers cultivation as well as local traditions and wisdom. Several actors were determined to improve Cihideung area. It was to develop the village not to be merely agrotourism, but also possess tradition and local wisdom attraction capable to strengthen local cultural identity.

Comparison between procession sequences of ngalokat jeung ngaruat sirah cai or numbal sirah cai (water spring sacrifice) and Upacara Irung-irung is defined in Table 2.

Comparison of ritual processions of numbal sirah cai and Upacara Irung-irung exhibits several differences. The differences in numbal sirah cai and Upacara Irung-irung answers the research question.

\section{CONCLUSION}

Research result concluded that Upacara Irung-irung in an endeavor to revitalize numbal sirah cai through happening art approach is not the ritual ceremony. Moreover, Upacara Irung-irung not connected with tribal communities in pre-industrial communities, but post-industry communities. The support community is not homogeneous, but heterogeneous which is bound on the basis of certain interests. The purpose of activities for the benefit of tourism and the development of contemporary art is based on local wisdom. Upacara Irungirung becomes a spectacle of contemporary art that teaches how important it is to preserve the sustainability of springs.

Research result found several activities during Upacara Irung-irung which violates taboos in numbal sirah cai. For instance, performers danced in the spring. People plunged themselves into the spring. Garut sacrifical sheep's blood flowed into the spring. The aforementioned activities conducted during Upacara Irung-irung were taboo or prohibition in the norms of preserving water sources.

\section{REFERENCES}

1. Ayesha, Ivonne. (2016). Analisis Rantai Pasokan Komoditas Florikultura sebagai Upaya Peningkatan Ekonomi Masyarakat di Kabupaten Bandung Barat. Jurnal Mimbar Agribisnis, 1(2): 133-138.

2. Giddens, Anthony. (2001). Runaway World: Bagaimana Globalisasi Merombak Kehidupan Kita. Translated by A. Kristiawan \& Y. Koen. Edited by A.P. Kuntjoro. Jakarta: Gramedia Pustaka Utama.

3. Giddens, A. (1994). Masyarakat Pos-tradisional. Penerjemah Ali Noer Zaman. Edited by E.A.H. lyubenu. Yogyakarta: IRCiSoD.

4. Haedicke, S.C. (2013). Contemporary Streets Arts in Europe Aesthetics and Politics. New York: Palgrave MacMillan.

5. Hansen, A. (1965). A Primer of Happenings and Time/Space Art. New York: Something Else Press, Inc.

6. Herlinawati, L. (2011). ."Ngaruat Solokan di Desa Cihideung Kecamatan Parongpong Kabupaten Bandung Barat" dalam Jurnal Balai Pelestarian Nilai Budaya Bangsa Kementerian Pendidikan dan Kebudayaan Patanjala, 3(2)P.22-34

7. Hobsbawm, Eric and Terence Ranger (Eds.). (1983). "Introduction". The Invention of Tradition. The Cambridge of University Press: New York. 
8. Hudayana, Bambang, Sri Retna Astuti, Emiliana Sadilah, Suseno Dwi Hantoro, Ardana Kusumawanto, Nouruz Zaman Okhtaby.(2012). Ritual Adat Ujungan Desa Gumelem Wetan Kecamatan Susukan Kabupaten Banjarnegara Jawa Tengah. Yogyakarta: Balai Pelestarian Nilai Budaya (BPNB) Yogyakarta dan Fakultas IImu Budaya Universitas Gadjah Mada.

9. Indiyanto, Agus, Dwi Ratna Nurhajarini, Salamun, Siti Munawaroh, Gilang Permata Sari, Rakhmat Nurdiansyah, Bimo Haryo Yudhanto. (2012). Revitalisasi Ritual Adat dalam Rangka Ketahanan Budaya Lokal: Kasus Ritual Nyanggring di Desa Tlemang Kecamatan Ngimbang Kabupaten Lamongan Jawa Timur. Yogyakarta: Balai Pelestarian Nilai Budaya (BPNB) Yogyakarta dan Fakultas IImu Budaya Universitas Gadjah Mada.

10. Reza, R.M. (2009). Cingcowong di Kuningan Jawa Barat: Alih-ubah dari Ritual ke Tari Pertunjukan. Unpublished Thesis, Cultural Study Program, Faculty of Cultural Studies. Depok (Jawa Barat): Universitas Indonesia.

11. Rusnanto. (2010). Upacara Tradisional Rahengan di Desa Citatah Kecamatan Cipatat dan Upacara Hajat Cai di Desa Cihideung Kecamatan Parongpong Kabupaten Bandung Barat. Unpublished Research Report. Dinas Kebudayaan dan Pariwisata Kabupaten Bandung Barat.

12. Sugiharto, I.B. (Ed.).(2013). Untuk apa seni? Bandung: Matahari.

13. Sutiyono \& Seriati, N.N. (2013). "Pemberdayaan Masyarakat Desa dalam Melaksanakan Revitalisasi Budaya Lokal 'Bersih Desa' di Ketingan, Sleman, Daerah Istimewa Yogyakarta". Jurnal Penelitian Humaniora Universitas Gadjah Mada, 18(1): 30-38.

14. Sztompka, Piötr. (2010). Sosiologi Perubahan Sosial. Jakarta: Prenada Media.

15. Turner, V.W. (1974). The Ritual Process, Structure and Anti Structure. Harmondsworth: Pinguin Books.

16. Turner, V.W. (1982). From Ritual to Theatre: The Human Seriousness of Play. London: The Johns Hopkins Press, Ltd.

17. Winangun, Y.W.W. (1990). Masyarakat Bebas Struktur: Liminalitas dan Komunitas menurut Victor Turner. Yogyakarta: Kanisius. 